\title{
Microarray profiling of human white adipose tissue after exogenous leptin injection
}

Citation for published version (APA):

Taleb, S., van Haaften, R. I. M., Henegar, C., Hukshorn, C. J., Cancello, R., Pelloux, V., Hanczar, B., Viguerie, N., Langin, D., Evelo, C. T. A., Zucker, J. D., Clement, K., \& Saris, W. H. M. (2006). Microarray profiling of human white adipose tissue after exogenous leptin injection. European Journal of Clinical Investigation, 36(3), 153-163. https://doi.org/10.1111/j.1365-2362.2006.01614.x

Document status and date:

Published: 01/01/2006

DOI:

10.1111/j.1365-2362.2006.01614.x

Document Version:

Publisher's PDF, also known as Version of record

\section{Please check the document version of this publication:}

- A submitted manuscript is the version of the article upon submission and before peer-review. There can be important differences between the submitted version and the official published version of record.

People interested in the research are advised to contact the author for the final version of the publication, or visit the DOI to the publisher's website.

- The final author version and the galley proof are versions of the publication after peer review.

- The final published version features the final layout of the paper including the volume, issue and page numbers.

Link to publication

\footnotetext{
General rights rights.

- You may freely distribute the URL identifying the publication in the public portal. please follow below link for the End User Agreement:

www.umlib.nl/taverne-license

Take down policy

If you believe that this document breaches copyright please contact us at:

repository@maastrichtuniversity.nl

providing details and we will investigate your claim.
}

Copyright and moral rights for the publications made accessible in the public portal are retained by the authors and/or other copyright owners and it is a condition of accessing publications that users recognise and abide by the legal requirements associated with these

- Users may download and print one copy of any publication from the public portal for the purpose of private study or research.

- You may not further distribute the material or use it for any profit-making activity or commercial gain

If the publication is distributed under the terms of Article $25 \mathrm{fa}$ of the Dutch Copyright Act, indicated by the "Taverne" license above, 


\title{
Microarray profiling of human white adipose tissue after exogenous leptin injection
}

\author{
S. Taleb ${ }^{*}$, R. Van Haaften ${ }^{\S}$, C. Henegar ${ }^{*}$, C. Hukshorn ${ }^{\S}$, R. Cancello*, V. Pelloux*, B. Hanczar ${ }^{*}$, \\ N. Viguerie", D. Langin", C. Evelo ${ }^{\dagger \S}$, J. Zucker ${ }^{*}$, K. Clément ${ }^{*}$ and W. H. M. Saris ${ }^{\S}$ \\ ${ }^{\star}$ Nutriomique U755; Université Pierre et Marie Curie; Hôtel-Dieu, Paris, France, ${ }^{\dagger}$ Technical University Eindhoven, \\ Eindhoven, the Netherlands, ${ }^{\ddagger}$ Paris-Nord University, Bobigny, France, ${ }^{\circledR}$ University of Maastricht, Maastricht, \\ The Netherlands, "Louis Bugnard Institute; University Paul Sabatier; CHRU, Toulouse, France
}

Abstract

\begin{abstract}
Abbreviations: Body, mass index (BMI); false, discovery rate (FDR); gene, ontology (GO); GenMAPP, (Gene Map Annotator Pathway Profiler); high, sensitive C reactive protein (hsCRP); interleukin, (IL); microarray, pathway profiles (MAPPs); polyethylene, glycol-leptin (PEG-OB); real-time, quantitative PCR (RT-PCR); serum, amyloid A (SAA); significance, analysis microarray (SAM); stroma, vascular fraction (SVF); white, adipose tissue (WAT).
\end{abstract}

INSERM, Nutriomique U755, 75004 Paris, France; Université Pierre et Marie Curie, Faculté de Médecine, Les Cordeliers, 75004 Paris, France; AP-HP, Pitié Salpétrière, Service de Nutrition, Hôtel-Dieu, 75004 Paris, France (S. Taleb, C. Henegar, R. Cancello, V. Pelloux, B. Hanczar, J. Zucker, K. Clément); BiGCaT Bioinformatics, Technical University Eindhoven, Eindhoven, the Netherlands (C. Evelo); Paris-Nord University, LIM \& BIO, Bobigny, France (C. Henegar, B. Hanczar, J. Zucker); Nutrition and Toxicology Research Institute NUTRIM, University of Maastricht, Maastricht, the Netherlands (R. van Haaften, C. Hukshorn, C. Evelo, W. H. M. Saris); INSERM U586, Unité de Reserches sur les Obésités, Toulouse, F-31432, France (N. Viguerie, D. Langin).

Correspondence to: Professor Karine Clément, INSERM Avenir, Nutrition Department, Hôtel-Dieu, Place du Parvis Notre-Dame, 75004 Paris, France. Tel.: +33 (0) 1423486 70; fax: +33 (0) 1405100 57; e-mail: karine.clement@htd.ap-hop-paris.fr

Received 31 October 2005; accepted 8 January 2006 
Table 1 Clinical and biochemical characteristics of nonobese men treated with a single supraphysiological dose of polyethylene glycolOB protein

\begin{tabular}{lcc}
\hline & Before PEG-OB injection (day 0) & After PEG-OB injection (day 3) \\
\hline Number & 10 & 10 \\
Age $(\mathrm{y})$ & $25 \cdot 9 \pm 4 \cdot 1$ & - \\
Weight $(\mathrm{kg})$ & $77 \cdot 65 \pm 3 \cdot 07$ & $77 \cdot 5 \pm 3 \cdot 1$ \\
BMI $\left(\mathrm{kg} \mathrm{m}^{-2}\right)$ & $23 \cdot 1 \pm 0 \cdot 65$ & $23 \cdot 1 \pm 0 \cdot 62$ \\
Leptin $\left(\mu \mathrm{mol} \mathrm{L}^{-1}\right)$ & $2 \cdot 61 \pm 0 \cdot 75$ & $2111 \cdot 4 \pm 175 \cdot 53^{\star}$ \\
Insulin $\left(\mathrm{U} \mathrm{mL}^{-1}\right)$ & $5 \cdot 82 \pm 1 \cdot 08$ & $6 \cdot 09 \pm 1 \cdot 36$ \\
Adiponectin $\left(\mu \mathrm{gL} \mathrm{mL}^{-1}\right)$ & $7 \cdot 61 \pm 0 \cdot 93$ & $7 \cdot 19 \pm 0 \cdot 91$ \\
$\mathrm{HsCRP}\left(\mathrm{mg} \mathrm{dL}^{-1}\right)$ & $0 \cdot 134 \pm 0 \cdot 053$ & $0 \cdot 293 \pm 0 \cdot 13$ \\
SAA $(\mu \mathrm{g} \mathrm{mL})$ & $5 \cdot 31 \pm 1 \cdot 58$ & $17 \cdot 82 \pm 7 \cdot 06$ \\
\hline
\end{tabular}

Data are expressed as mean \pm SEM.

PEG-OB, polyethylene glycol-OB protein.

${ }^{\star}$ Mean fold increase of circulating leptin is approximately 809 -fold.

\section{Introduction}

The leptin hormone is mainly produced by the white adipose tissue (WAT) and plays a key role in body weight homeostasis [1]. The changes in circulating leptin levels reflect the nutritional status and provides a feedback signal from the periphery to the central nervous system $[1,2]$. Thus, leptin satisfies the criteria for the long-sought 'Lipostat' molecule of the adipostatic model, which was postulated to explain the relative stability of weight over time. In healthy animals [3], as in humans [4], circulating concentrations of leptin are highly correlated with body fat mass; it crosses the blood-brain barrier and interacts with neurones known to decrease food intake and stimulate thermogenesis [5]. In addition to its central action on food intake and energy expenditure, leptin may also be endowed with direct peripheral effects on nonadipose tissue (i.e. muscle, liver, haematopoetic cells) to exert a role on different functional pathways such as angiogenesis, inflammation and immunity as well as fat oxidation [6-9]. However, the peripheral effect of leptin on adipose tissue physiology is still debated $[10,11]$.

Leptin appears as a survival hormone aimed at maintaining the energy balance, representing the first strategy for obesity treatment. Unfortunately, except for the rare forms of monogenic obesity with leptin deficiency [12], the majority of obesity cases are associated with high levels of circulating leptin, and the emerged idea was that obese patients are resistant to the action of leptin [13]. Human trials performed with leptin treatment have shown that most subjects are unlikely to respond to pharmacological treatment with this hormone [14-16]. The widespread occurrence of leptin resistance might reflect the fact that the inability to store energy efficiently at times of abundance is evolutionarily disadvantageous. According to this alternative view, leptin has a broader physiological role and evolved as a signal whose reduction indicates starvation [17]. In some cases, leptin induces moderate fat loss especially under conditions of energy restriction indicating some action of leptin on WAT $[14,18]$.The physiological functions related to this feedback signal, which can eventually be modulated in adipose tissue by leptin treatment, are mostly unknown.

In this study, we hypothesized that even if leptin administration had a limited effect on body fat loss, it could act on gene expression of known or unknown targets in WAT. Our purpose was to identify gene targets and functional pathways of leptin in human adipose tissue. To this end, we compared gene expression profiles in WAT of seven lean male subjects before and after $72 \mathrm{~h}$ of administration leading to a high peak of leptin in the circulation. In order to capture functions that might be significantly affected by PEG-OB treatment, different methods of gene annotation were used. Our results showed that functional processes related to immunity and inflammation were among the most affected functions after PEG-OB treatment in WAT of healthy nonobese subjects.

\section{Materials and methods}

\section{PEG-OB}

Modification of proteins through covalent linkage of polyethylene glycol polymers to the proteins results in reduced immunogenicity and increased serum half-life for many proteins. Recombinant native human PEG-OB, expressed and purified from Escherichia coli, was chemically conjugated to a species of branched PEGs with an average molecular mass of $42 \mathrm{kDa}$ in a $1: 1$ ratio. PEG is not metabolized and excreted completely. The result was a globular PEG-native human PEG-OB polymer with increased molecular size. A volume of $1.3 \mathrm{~mL}$ PEG-OB at a concentration of $10 \mathrm{mg} \mathrm{mL}^{-1}$ was placed in sterile glass vials (Hoffmann-La Roche Inc., Nutley, NJ). Preclinical studies with PEG-OB indicate an extended half-life ( $>48 \mathrm{~h}$ ) and efficacy for reduction of food intake and body weight in animals [19]. Our previous study in obese male subjects clearly showed sustained elevated blood concentrations after weekly subcutaneous dosing of PEGOB in humans. Mean peak serum PEG-OB concentrations were achieved $72 \mathrm{~h}$ after dosing, followed by a return to the elevated predose concentrations after 1 week [15]. 


\section{Subjects and study design}

Ten nonobese caucasian men (age 21-27 years, body mass index $20-26 \mathrm{~kg} \mathrm{~m}^{-2}$ ) were recruited through a local advertisement. All subjects had a stable weight and were healthy according to their medical history, clinical examination and routine laboratory findings. The study was approved by the medical Ethics Committee of the University of Maastricht, and all participants gave written informed consent. The leptin treatment consisted of an 80-mg PEG-OB injection in the para-umbilical region. Blood and WAT biopsies were obtained from fasted subjects on day 0 (before the PEGOB treatment) and $72 \mathrm{~h}$ after the injection. At this time, PEG-OB concentration was approximately 809-fold higher compared with basal levels (Table 1).

\section{Biochemical measures}

Plasma leptin levels were measured by a double-antibody sandwich ELISA using a monoclonal antibody specific for human leptin. This assay measures total leptin [15]. Serum insulin $\left(\mathrm{mU} \mathrm{L}^{-1}\right)$ was measured with immunoradiometric assay (IRMA) (Bi-INSULINE IRMA CisBio International, Gif-sur-Yvette, France). Serum adiponectin concentrations were determined using standard kits (Linco Research, Saint Louis, MI). High sensitive $\mathrm{C}$ reactive protein circulating levels were measured using an IMMAGE automatic immunoassay system (Beckmann-Coulter, Fullerton, CA).

\section{Total RNA preparation}

Human white subcutaneous adipose tissues were homogenized in lysis buffer (RLT buffer, Qiagen, Cour taboeuf, France) using a rotator-stator, followed by a chloroform delipidation step. The upper aqueous phase was processed for total RNA extraction using silica-based spin columns (RNeasy Mini Kit, Qiagen Protocol). The yield ofWAT total RNA was 3-7 $\mu \mathrm{g} \mathrm{g}^{-1}$ WAT. The RNA concentration was determined by measuring absorbance at $260 \mathrm{~nm}$ and the purity was estimated by $260 / 280 \mathrm{~nm}$ absorbance ratio. Total RNA integrity was verified by agarose gel electrophoresis or using an Agilent 2100 Bioanalyser (Agilent, Paris, France). We obtained high-quality RNA, mandatory for microarray in seven subjects.

A reference pool containing adipose tissue RNAs from 14 healthy subjects was used to compare data from different experiments. Equivalents of $15 \mu \mathrm{g}$ of total RNA from each of the 14 healthy subjects were mixed together in order to constitute a pool of total RNA [20].

\section{RNA amplification and microarray experiments}

RNA preparations from the seven subjects were amplified using MessageAmp aRNA protocol (Ambion, Cambridgeshire, UK) in order to generate a sufficient amount of labelled hybridization samples to cDNA microarrays [20]. Briefly, the procedure consists of reverse transcription of
$5 \mu \mathrm{g}$ total RNA using Primer Oligo dT bearing a T7 promoter sequence, followed by in vitro $\mathrm{T} 7 \mathrm{RNA}$ polymerase transcription of cDNA to generate RNA antisense copies of each messenger RNA. This amplification procedure is now generally accepted and it has been demonstrated that it does not distort the relative abundance of a single mRNA within a RNA population [21]. Briefly, $3 \mu \mathrm{g}$ antisense RNA was labelled by incorporating Cyanine dyes (Amersham Pharmacia Biotech, Orsay, France) during random reverse transcription with Cyscript (Cyscribe first-strand cDNA labelling kit, Amersham Pharmacia Biotech). Amplified RNA from the seven healthy men before and after PEGOB treatment was labelled with Cy5, whereas amplified RNA from the reference pool was labelled with Cy3. The labelled mixture (Cy5 and Cy3) was purified and concentrated using Microcon YM 30 column (Millipore, Bedford, MA) after the addition of human cot-1, yeast tRNA and poly A. After denaturation of probes, the mixture was hybridized overnight on 14 slides (seven slides both before and after treatment) at $65^{\circ} \mathrm{C}$ in a sealed humidified hybridization chamber, and then washed in 0.03 SDS, 2XSSC, 1XSSC and $0.2 \mathrm{SSC}$ solutions for $2 \mathrm{~min}$. After washing, the arrays were immediately scanned using a Genepix 4000 A Scanner (Axon Instrument, Union City, CA). Images were analyzed using Genepix Pro 3 software where spots with bad quality were omitted. Data files generated by Genepix were entered in Stanford microarray database. The spots with an average intensity less than $2 \cdot 5$-fold above the background were removed. A uniform scale factor was applied to all measured intensities in order to normalize signal intensities between Cy5 and Cy3. The data of 14 slides were normalized in log-space using Locally Weighted Linear Regression (Lowess) [22]. In order to identify the genes that were significantly regulated by PEG-OB injection, we used the Significance $A$ nalysis $M$ icroarray (SAM) procedure, a validated statistical technique for identifying differentially expressed genes across high-density microarrays. SAM is a nonparametric method by which a modified $t$-statistic $d(i)=x(i) /$ $\left[s(i)+s_{0}\right]$ is calculated for the $i^{\text {th }}$ gene, where $x(i)$ is the mean of the $\log _{2}$ ratio data across all seven experiments and $s(i)$ is the appropriately scaled standard deviation. The quantity $s_{0}$ is an adjustment factor derived from the data which attempts to make $d(i)$ independent of $s(i)$. Because the null hypothesis was that there was no treatment effect, we tested whether the expected value of the $\log _{2}$ ratio is 0 in the statistic $d(i)$. The FDR (False Discovery Rate) method controls the expected value of the number of false positives to the total number of genes. For this experiment the FDR was set at a value of $5 \%$.

\section{Quantification of mRNA levels by real-time PCR}

Total RNA was extracted using Rneasy, as described earlier. Reverse transcription was performed with $1 \mu \mathrm{g}$ total RNA for each biopsy, and $10 \mathrm{ng}$ cDNA was used as template for RT-PCR as recommended by the manufacturer (Applied Biosystems, Foster City, CA). We used 18S ribosomal RNA as control to normalize gene expression (Applied Biosystems). 
The PCR was performed on the ABI PRISM 7000 Sequence Detection System (Applied Biosystems, Minneapolis, MN) using the TaqMan Reverse Universal PCR Master Mix and Assays-on-Demand Gene Expression probes (Applied Biosystems) which contain a mixture of forward and reverse oligonucleotide primers and a specific TaqMan probe (Applied Biosystems).

The probe was labelled at the $5^{\prime}$ end with the reporter dye, 6-carboxy-fluorescein (FAM) and at the $3^{\prime}$ end with the quencher, 6-minor groove binder (MGB). The assay identification number of the probes used are available on the Applied Biosystem website.

Each reaction well contained cDNA, TaqMan PCR Master Mix, $900 \mathrm{nmol} \mathrm{L}^{-1}$ of each primer and $250 \mathrm{nmol} \mathrm{L}^{-1}$ of TaqMan probe. Cycling parameters were standardized as $50^{\circ} \mathrm{C}$ for $2 \mathrm{~min}, 95$ for $10 \mathrm{~min}$, then 40 cycles of $95^{\circ} \mathrm{C}$ for $15 \mathrm{~s}$ and $60^{\circ} \mathrm{C}$ for $1 \mathrm{~min}$.

TaqMan reagent-based chemistry uses a fluogenic probe to enable detection of a specific PCR product as it accumulates during PCR cycles. When both quencher and reporter are attached to the probe, reporter dye emission is quenched. During each extension cycle at $60{ }^{\circ} \mathrm{C}$, the polymerase cleaves the reporter dye from the probe. After being separated from the quencher, the reporter dye emits its characteristic fluorescence.

A standard curve for each primer pair was obtained using serial dilutions of WAT cDNA. A standard curve for serial dilutions of $18 \mathrm{~S}$ rRNA was similarly generated. The Ct represents the threshold cycle number at which the fluorescence signal is linearly increasing above background. The Ct readings for unknown samples were used to calculate the amount of each target gene relative to $18 \mathrm{~S}$. The relative standard curve method (Applied Biosystems) was used to calculate the amplification difference between the before and after PEG-OB treatment for each primer set.

\section{Isolation of human white adipocytes and stroma vascular fraction}

To determine whether differentially expressed genes were mainly expressed in adipocytes, stroma vascular fraction (SVF) or equally in adipocytes and SVF, we performed sets of experiments aimed at isolating adipocytes from the stromal cells, as described [20]. Briefly, stroma vascular fraction and adipocytes were separated after adipose tissue digestion and centrifugation. Total RNAs obtained from adipocytes and SVF cells were extracted and a set of microarray experiments were realized to distinguish genes expressed in adipocyte from those expressed in SVF cells [20].

\section{Capture of enriched functions after PEG-OB treatment}

A functional profiling of PEG-OB regulated genes was realized by using the Gene Ontology Consortium (GO, http:// www.geneontology.org/), which provides a controlled vocabulary to describe gene and gene product attributes in any organism [23]. We used GO through an 'in-house' automated annotation procedure (Henegar C, Bioinformatics in revision). In order to assure a correct over-representation analysis, LocusLink numbers were used as the standard gene accession system (SGA), allowing us to map gene identifiers to GO functional annotations in an unequivocal way. The GO hierarchical structure allows the characterization of genes with a variable biological term precision (generic terms and/or more specific terms based on the hierarchical levels), and then the annotation procedure aimed to favour the selection of the most specific GO categories against more general ones. A gene-enrichment measure was computed for each GO category by restricting annotation inheritance only to the genes directly related to its direct subsumes within the ontological hierarchy. The significance of the gene enrichment for each GO category was assessed by calculating a $P$-value. This $P$-value estimates the probability that the observed number of differentially regulated genes (annotated by a specific GO category) could have resulted from random distribution between the tested list of differentially regulated genes in the experiment, for which at least one GO annotation was identified, and a reference list. The reference list included all the genes available on the entire microarray, which were tested for differential regulation during the experiment and which had at least one GO annotation. As many of the identified GO categories had less than five annotations, a unilateral Fisher exact test was used for $P$-value calculations. Only GO categories showing significant gene enrichment (after $P$-value correction for a $5 \%$ false discovery rate) were selected and used for further processing. In order to facilitate the analysis of functional profiles, we clustered together all related GO categories, based on the sharing of a significant number of annotated genes (Henegar C, Bioinformatics in revision). As for the individual GO categories, a $P$-value of gene enrichment significance was calculated for each of the identified clusters, by using a unilateral Fisher exact test, and then the clusters were ranked based on the statistical significance of the gene space coverage. Gene annotation procedure was realized separately for each of the three available ontologies: molecular function, biological process and cellular component. As 'biological process' annotations were the more exhaustive and immediately comprehensive, they are presented in this study.

The second method used is the visualization tool GenMAPP (Gene Map Annotator Pathway Profiler) version 2.0 (http://www.genmapp.org). This is a program for viewing and analyzing microarray data on microarray pathway profiles (MAPPs) representing biological pathways or any other functional grouping of genes [24]. Microarray pathway profiles are generated from several public and commercial pathway resources currently in existence, including:

- GO database and G-protein Coupled Receptor Database (http://www.gpcr.org, database on G-protein and their interactions with their receptors) [25];

- a small number of MAPPs based on the KEGG database (http://www.genome.ad.jp/kegg, database integrating knowledge on molecular interaction networks in biological processes, the information about the universe of genes and proteins, and the information about the universe of chemical compounds and reactions) [26];

- MAPPS specifically designed for GenMAPP. 
Table 2 Validation of microarray results using quantitative real-time quantitative PCR

\begin{tabular}{llllll}
\hline Response to leptin & UG cluster & Name & Ratio array & Ratio RT-PCR & $P$-value \\
\hline Down & Hs 234734 & Lysozyme & $-2 \cdot 39$ & $-2 \cdot 22$ & $0 \cdot 01$ \\
& Hs 82848 & Selectin L & $-2 \cdot 13$ & $-1 \cdot 88$ & $-2 \cdot 00$ \\
& Hs 181301 & Cathepsin S & $-1 \cdot 91$ & $-1 \cdot 56$ & $-1 \cdot 64$ \\
& Hs 196352 & Neutrophile cytosolic factor 4 & $-2 \cdot 07$ & $-1 \cdot 85$ & $0 \cdot 07$ \\
& Hs 76930 & Synuclein alpha & $-1 \cdot 45$ & $-1 \cdot 63$ & $0 \cdot 01$ \\
& Hs 241392 & Chemokines CCL5 & $-1 \cdot 45$ & $-2 \cdot 85$ & $-2 \cdot 63$ \\
& Hs 75703 & Chemokines CCL4 & $-1 \cdot 87$ & $-2 \cdot 27$ & $0 \cdot 03$ \\
Nonsignificant & Hs 174228 & Chemokine XCL1 & $-1 \cdot 86$ & $-1 \cdot 3$ & $0 \cdot 09$ \\
\hline
\end{tabular}

Fold changes in mRNA levels of 10 randomly chosen genes were determined by real-time PCR (RT-PCR) on total RNA from the seven subjects.

$P$-values were calculated using the nonparametric Wilcoxon test.

Microarray experiments were performed on amplified RNA from seven subjects. Microsomal glutathione S-transferase (MGST1) is a control gene of which the fold change did not significantly change in real-time PCR and microarray experiments.

The MAPPS from the G-protein Coupled Receptor Database, KEGG database and the specifically designed MAPPS are called the local MAPPS. We imported the median gene expression data of the significant gene group, sorted by SAM, into the program and used GenMAPP to illustrate pathways containing differentially expressed genes. The obtained illustrations show presence and expression changes for the genes presented on the microarray based on the analysis of PEG-OB treatment versus control. All the gene expression data are dynamically linked to the MAPPs with a tool called MAPPFinder [27]. For all the imported genes MAPPFinder calculates the percentage of genes measured that meet a user-defined criterion (fold change $>1.4$ or $<-1.4$ ) and a z-score. The z-score is a standardized difference-score using the expected value and standard deviation of the number of genes meeting the criterion on a MAPP. The z-score attempts to take into account that a larger fraction of changed genes is less likely to occur in a large MAPP than is a small one.

\section{Statistical analysis}

Data are expressed as mean \pm SEM. Statistical analysis was performed with JMP statistic software (SAS Institute Inc., Cary, NC). Differences in means of clinical and biochemical parameters of subjects before and after PEG-OB treatment were determined using the Wilcoxon nonparametric paired test. Significance of correlation between circulating levels of CRP and SAA was examined using the nonparametric Spearman's rank.

\section{Results}

\section{Effect of PEG-OB injection on clinical and biochemical parameters}

The baseline characteristics of the subjects and changes after $72 \mathrm{~h}$ of PEG-OB injection are shown in Table 1. While the circulating leptin increased approximately 809-fold, the weight of the subjects, insulin as well as the adipokine adiponectin did not change after the PEG-OB injection (Table 1). The inflammatory factors CRP and SAA tended to increase after the PEG-OB injection. However, these increases were not significant (CRP fold increase $=2 \cdot 18$, $P=0 \cdot 27$; SAA fold increase $=3 \cdot 35, P=0 \cdot 055)$. There was a strong positive correlation between variations of circulating CRP and SAA levels under the PEG-OB injection $(r=0.93, P<0.0001)$.

\section{PEG-OB treatment mobilized genes in human WAT}

Our gene profiling experiment was performed with total RNA preparation from WAT of seven healthy men before and after $72 \mathrm{~h}$ of PEG-OB treatment, leading to a 809 -fold increase in circulating serum leptin. We started to analyze the expression of $40844 \mathrm{cDNAs}$ printed on a glass slide. After normalization, filtering procedures and use of the SAM program, we found $1922 \mathrm{cDNAs}$ with significant changes using an estimated FDR of 5\%. These cDNAs included 1822 downly expressed and 100 overexpressed genes.

Using RT-PCR, we confirmed the changes in expression of nine genes, including chemokines (CCL5, CCL4, $\mathrm{XCL} 1$ ), TNF superfamily factor 3 and other inflammatoryrelated factors like cathepsin $\mathrm{S}$, selectin $\mathrm{L}$ and neutrophile cytosolic factor 4 (Table 2). In agreement with microarray findings, MGST1 gene expression was not changed in RTPCR experiments.

\section{Enriched functions of PEG-OB mobilized genes in WAT}

We further searched for the functional classes that were significantly captured by the PEG-OB injection in WAT. Although no significant cluster of enriched functions was identified in the group of overexpressed genes (data not 

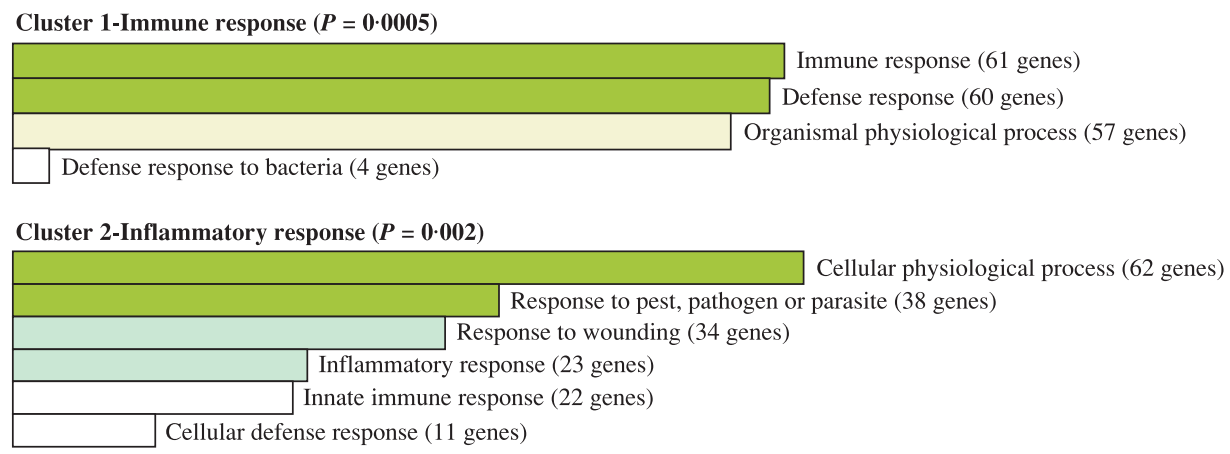

Cluster 3-Embryonic development $(\boldsymbol{P}=\mathbf{0 . 0 0 8})$

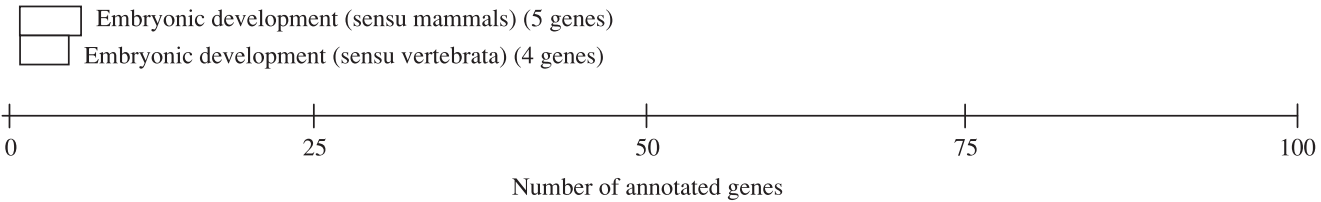

Figure 1 Schematic representation of enriched functions in the group of polyethylene glycol-leptin down-regulated genes. The clusters of enriched functions are listed by $P$-value score (after adjustment with the Benjamini \& Hochberg FDR method) and the figure shows the three significant clusters of genes. The number of genes annotated by a given gene ontology function (biological process) is indicated in the parenthesis.

shown), the GO biological process based on automatic annotation revealed different sets of enriched functions in the group of down-regulated genes. Three significant functional clusters were enlightened as illustrated in Fig. 1. The first two significant clusters included genes related to immunity and inflammatory functions (Fig. 1). The third cluster was related to embryonic development functions.

For examination of more specific changes after the PEG$\mathrm{OB}$ injection, the functional grouping of genes modified by the PEG-OB injection was systematically evaluated for differential regulation using the visualization tool GenMAPP. We found genes significantly modified by the PEG-OB injection in eight local MAPPS (Table 3). In agreement with our first functional analysis, the inflammatory response pathway was among the local pathways most down-regulated after the PEG-OB injection (Table 3).

Other local MAPPs identified were nucleotide metabolism, peptide GPCRs, apoptosis, TGF beta signalling, synthesis and degradation of ketone bodies, pentose phosphate pathway and proteasome degradation (Table 3). The MAPPs were ranked with a decreasing z-score. More positive $z$-scores suggest with more confidence that the correlation between the expression changes of the genes in this MAPP are not occurring by chance alone. Taken together, these results indicate that adipose tissue genes related to inflammation and immunity were significantly down-regulated by the supraphysiological dose of the PEG-OB injection.

Table 3 GenMAPP pathways affected by leptin treatment

\begin{tabular}{|c|c|c|c|c|}
\hline Pathway MAPP name & z-score & $\begin{array}{l}\text { Genes } \\
\text { changed }\end{array}$ & $\begin{array}{l}\text { Reporters } \\
\text { present }\end{array}$ & $\begin{array}{l}\text { Genes on } \\
\text { MAPP }\end{array}$ \\
\hline Hs_inflammatory response pathway & $1 \cdot 588$ & 3 & 5 & 31 \\
\hline Hs_nucleotide metabolism & $1 \cdot 588$ & 3 & 5 & 16 \\
\hline Hs_peptide GPCRs & $1 \cdot 377$ & 4 & 8 & 69 \\
\hline Hs_apoptosis & $0 \cdot 977$ & 2 & 4 & 43 \\
\hline Hs_TGF beta signalling pathway & $0 \cdot 831$ & 5 & 13 & 51 \\
\hline Hs_synthesis and degradation of ketone bodies & $0 \cdot 692$ & 1 & 2 & 5 \\
\hline Hs_pentose phosphate pathway & $0 \cdot 692$ & 1 & 2 & 7 \\
\hline Hs_proteasome degradation & $0 \cdot 285$ & 5 & 16 & 42 \\
\hline
\end{tabular}

The table shows a ranked list of processes with a relatively high number of gene expression values found to be changed. The z-score is calculated as the number of genes changed (fold change $>1.4$ ) in a pathway minus the number of expected changes based on the number of genes present in the pathway MAPP and the total fraction of genes changed for all MAPPs, divided by the standard deviation of the observed number of changes in all MAPPs. High z-scores indicate pathways where relatively many changes occurred. Note that the $z$-score also depends on the coverage of the pathway genes by the successfully annotated microarray reporter content. Next to the number of changed genes, the number of reporters for that pathway on the array and the total number of genes in the pathway MAPP are also given (cf. Methods). 
In our study in healthy nonobese males, we observed a decreased expression of factors bearing proinflammatory properties in human adipose tissue under PEG-OB treatment. Several of these genes encoded for inflammatory factors are potentially secreted, such as chemokines with Cys (XCL1), Cys-Cys (CCL 2, 4, 5, 18, 19, 26) Cys-x-Cys (CXCL 7, 4, 16) and Cys-x3-Cys (CX3CL1) motifs. These molecules have well-known chemotactic properties and proinflammatory effects. Other secreted factors are cytokines or related factors such as several members of the tumour necrosis factor superfamily ligand, interleukins (IL6, IL15,
IL16, IL13), interferon gamma (INF $\gamma$ ) and interferon inducible protein. These changes are associated with a decreased expression of many chemokines and interleukin receptors. Other genes encoded proteins with protease (cathepsin S, lysozyme) activities that have the ability to degrade antigens presented to immune cells. Genes encoding proteins that enable adhesion of immune cells, such as integrin alpha $\mathrm{X}$, selectin $\mathrm{L}$, selectin $\mathrm{P}$ ligand, carcinoembryonic antigen-related cell adhesion, CD4 and CD3 antigens, were also mobilized (Table 4).

To determine whether the major down-regulated PEG-OB

Table 4 Transcriptional effects of leptin on inflammatory related genes

\begin{tabular}{|c|c|c|}
\hline G cluster & Gene name & Fold change \\
\hline & Chemokines & \\
\hline Hs. 81564 & platelet factor 4 (chemokine (C-X-C motif) ligand 4 ) & $-1 \cdot 32$ \\
\hline Hs. 82407 & chemokine (C-X-C motif) ligand 16 & $-1 \cdot 33$ \\
\hline Hs. 80420 & chemokine (C-X3-C motif) ligand 1 & $-1 \cdot 41$ \\
\hline Hs. 50002 & chemokine (C-C motif) ligand 19 & $-1 \cdot 43$ \\
\hline Hs.75703 & chemokine (C-C motif) ligand 4 & $-1 \cdot 45$ \\
\hline Hs. 131342 & chemokine (C-C motif) ligand 26 & $-1 \cdot 46$ \\
\hline Hs. 241392 & chemokine (C-C motif) ligand 5 & $-1 \cdot 46$ \\
\hline Hs. 2164 & pro-platelet basic protein (chemokine (C-X-C motif) ligand 7) & $-1 \cdot 49$ \\
\hline Hs. 16530 & chemokine (C-C motif) ligand 18 (pulmonary and activation-regulated) & $-1 \cdot 76$ \\
\hline Hs. 174228 & $\begin{array}{l}\text { chemokine }(\mathrm{C} \text { motif) ligand } 1 \\
\text { Chemokine receptors }\end{array}$ & $-1 \cdot 88$ \\
\hline Hs.421986 & chemokine (C-X-C motif) receptor 4 & $-1 \cdot 42$ \\
\hline Hs. 458436 & chemokine (C-C motif) receptor-like 2 & $-1 \cdot 47$ \\
\hline Hs.301921 & chemokine (C-C motif) receptor 1 & $-1 \cdot 51$ \\
\hline Hs.395 & chemokine (C-C motif) receptor 2 & $-1 \cdot 57$ \\
\hline Hs.78913 & $\begin{array}{l}\text { chemokine (C-X3-C motif) receptor } 1 \\
\text { Cytokines, TNF superfamily and interferons }\end{array}$ & $-1 \cdot 80$ \\
\hline Hs. 105656 & small inducible cytokine subfamily E, member 1 (endothelial monocyte-activating) & $-1 \cdot 31$ \\
\hline Hs. 130210 & interleukin 6 (interferon, beta 2) & $-1 \cdot 34$ \\
\hline Hs. 168132 & interleukin 15 & $-1 \cdot 36$ \\
\hline Hs. 58831 & regulator of Fas-induced apoptosis & $-1 \cdot 37$ \\
\hline Hs. 856 & interferon, gamma & $-1 \cdot 38$ \\
\hline Hs. 170359 & interleukin 16 (lymphocyte chemoattractant factor) & $-1 \cdot 38$ \\
\hline Hs.415839 & tumour necrosis factor (ligand) superfamily, member 12 & $-1 \cdot 44$ \\
\hline Hs. 83795 & interferon regulatory factor 2 & $-1 \cdot 49$ \\
\hline Hs. 387871 & tumour necrosis factor (ligand) superfamily, member 10 & $-1 \cdot 56$ \\
\hline Hs. 845 & interleukin 13 & $-1 \cdot 58$ \\
\hline Hs. 169274 & interferon-induced protein with tetratricopeptide repeats 2 & $-1 \cdot 60$ \\
\hline Hs. 376208 & $\begin{array}{l}\text { lymphotoxin beta (TNF superfamily, member 3) } \\
\text { Cytokines and TNF superfamily receptors }\end{array}$ & $-1 \cdot 87$ \\
\hline Hs. 143527 & interleukin 1 receptor accessory protein & $-1 \cdot 35$ \\
\hline Hs. 272410 & toll-like receptor 8 & $-1 \cdot 42$ \\
\hline Hs.362807 & interleukin 7 receptor & $-1 \cdot 43$ \\
\hline Hs. 144748 & interferon (alpha, beta and omega) receptor 1 & $-1 \cdot 44$ \\
\hline Hs. 1314 & tumour necrosis factor receptor superfamily, member 8 & $-1 \cdot 47$ \\
\hline Hs.74647 & $\begin{array}{l}\text { T-cell receptor alpha locus } \\
\text { Adhesion }\end{array}$ & $-1 \cdot 80$ \\
\hline Hs. 13572 & calcium modulating ligand & 1.56 \\
\hline Hs. 10247 & activated leucocyte cell adhesion molecule & $-1 \cdot 35$ \\
\hline Hs. 2257 & vitronectin (serum spreading factor, somatomedin B, complement S-protein) & $-1 \cdot 36$ \\
\hline Hs. 17483 & CD4 antigen (p55) & $-1 \cdot 47$ \\
\hline Hs.3003 & CD3E antigen, epsilon polypeptide (TiT3 complex) & $-1 \cdot 48$ \\
\hline Hs. 54517 & ficolin (collagen/fibrinogen domain containing lectin) 2 (hucolin) & $-1 \cdot 48$ \\
\hline Hs. 381568 & immunoglobulin J polypeptide, linker protein for immunoglobulin alpha and mu polypeptides & $-1 \cdot 49$ \\
\hline
\end{tabular}


Table 4 (cont'd)

\begin{tabular}{|c|c|c|}
\hline G cluster & Gene name & Fold change \\
\hline Hs. 89575 & CD79B antigen (immunoglobulin-associated beta) & $-1 \cdot 56$ \\
\hline Hs. 95327 & CD3D antigen, delta polypeptide (TiT3 complex) & $-1 \cdot 58$ \\
\hline Hs.407861 & alpha-2-glycoprotein 1 , zinc & $-1 \cdot 60$ \\
\hline Hs.79630 & CD79A antigen (immunoglobulin-associated alpha) & $-1 \cdot 63$ \\
\hline Hs. 838 & CD80 antigen (CD28 antigen ligand $1, \mathrm{~B} 7-1$ antigen) & -1.99 \\
\hline Hs.434918 & carcinoembryonic antigen-related cell adhesion molecule 1 (biliary glycoprotein) & $-2 \cdot 00$ \\
\hline Hs. 82848 & selectin L (lymphocyte adhesion molecule 1) & $-2 \cdot 13$ \\
\hline Hs. 385521 & integrin, alpha X (antigen CD11C (p150), alpha polypeptide) & $-2 \cdot 31$ \\
\hline Hs. 423077 & $\begin{array}{l}\text { selectin } \mathrm{P} \text { ligand } \\
\text { Signal transduction }\end{array}$ & $-2 \cdot 99$ \\
\hline Hs.753 & formyl peptide receptor 1 & $-1 \cdot 42$ \\
\hline Hs. 433300 & Fc fragment of IgE, high affinity I, receptor for; gamma polypeptide & $-1 \cdot 46$ \\
\hline Hs.46 & platelet-activating factor receptor & $-1 \cdot 51$ \\
\hline Hs. 126384 & Fc fragment of IgG, low affinity IIb, receptor for (CD32) & $-1 \cdot 53$ \\
\hline Hs.44439 & suppressor of cytokine signalling 4 & $-1 \cdot 58$ \\
\hline Hs. 381027 & colony stimulating factor 3 receptor (granulocyte) & $-1 \cdot 65$ \\
\hline Hs. 46348 & $\begin{array}{l}\text { bradykinin receptor } \mathrm{B} 1 \\
\text { Transcriptional factors }\end{array}$ & $-1 \cdot 84$ \\
\hline Hs. 14453 & interferon consensus sequence binding protein 1 & $1 \cdot 83$ \\
\hline Hs. 374357 & nuclear factor related to kappa $\mathrm{B}$ binding protein & $-1 \cdot 31$ \\
\hline Hs. 433759 & barrier to autointegration factor 1 & $-1 \cdot 41$ \\
\hline Hs. 83795 & interferon regulatory factor 2 & $-1 \cdot 49$ \\
\hline Hs. 25647 & $\mathrm{v}$-fos FBJ murine osteosarcoma viral oncogene homolog & $-1 \cdot 50$ \\
\hline Hs. 105434 & interferon stimulated gene $20 \mathrm{kDa}$ & $-1 \cdot 62$ \\
\hline Hs. 41691 & basic leucine zipper transcription factor, ATF-like & $-1 \cdot 94$ \\
\hline Hs. 153837 & $\begin{array}{l}\text { myeloid cell nuclear differentiation antigen } \\
\text { Other related inflammatory genes }\end{array}$ & $-1 \cdot 96$ \\
\hline Hs.79241 & B-cell CLL/lymphoma 2 & $1 \cdot 64$ \\
\hline Hs.407442 & Homo sapiens TCRgamma alternate reading frame protein (TCRg) mRNA, complete cds & $-1 \cdot 33$ \\
\hline Hs. 169998 & bone marrow stromal cell antigen 1 & $-1 \cdot 38$ \\
\hline Hs. 2253 & complement component 2 & $-1 \cdot 38$ \\
\hline Hs. 146559 & angiopoietin-like factor & $-1 \cdot 39$ \\
\hline Hs. 381568 & immunoglobulin J polypeptide, linker protein for immunoglobulin alpha and mu polypeptides & $-1 \cdot 49$ \\
\hline Hs. 406238 & aldehyde oxidase 1 & $-1 \cdot 50$ \\
\hline Hs. 2563 & $\begin{array}{l}\text { tachykinin, precursor } 1 \text { (substance } \mathrm{K} \text {, substance } \mathrm{P} \text {, neurokinin } 1 \text {, neurokinin } 2 \text {, neuromedin } \mathrm{L} \text {, } \\
\text { neurokinin alpha, neuropeptide } \mathrm{K} \text {, neuropeptide gamma) }\end{array}$ & $-1 \cdot 55$ \\
\hline Hs. 100194 & arachidonate 5 -lipoxygenase-activating protein & $-1 \cdot 57$ \\
\hline Hs.407861 & alpha-2-glycoprotein 1 , zinc & $-1 \cdot 60$ \\
\hline Hs. 46465 & $\mathrm{~T}$ cell, immune regulator 1 , ATPase, $\mathrm{H}+$ transporting, lysosomal $\mathrm{V} 0$ protein a isoform 3 & $-1 \cdot 62$ \\
\hline Hs. 196352 & neutrophil cytosolic factor $4,40 \mathrm{kDa}$ & $-1 \cdot 64$ \\
\hline Hs. 414332 & $2^{\prime}-5^{\prime}$-oligoadenylate synthetase $2,69 / 71 \mathrm{kDa}$ & $-1 \cdot 81$ \\
\hline Hs. 105407 & ectodermal dysplasia 1 , anhidrotic & $-1 \cdot 85$ \\
\hline Hs. 181301 & cathepsin S & $-1 \cdot 91$ \\
\hline Hs.449439 & $\begin{array}{l}\text { Homo sapiens TCR BV3 mRNA for T cell receptor beta chain (CDR3 region), partial cds, } \\
\text { isolate:HTLV-1 myopathy case 3, clone:Tax tetramer-5. }\end{array}$ & $-1 \cdot 95$ \\
\hline Hs. 949 & neutrophil cytosolic factor $2(65 \mathrm{kDa}$, chronic granulomatous disease, autosomal 2) & -1.99 \\
\hline Hs. 2200 & perforin 1 (pore forming protein) & $-2 \cdot 30$ \\
\hline Hs. 234734 & lysozyme (renal amyloidosis) & $-2 \cdot 39$ \\
\hline
\end{tabular}

effect in WAT was related to the decrease of PEG-OB receptor $(\mathrm{Ob}-\mathrm{Rb})$ expression under PEG-OB treatment we analyzed the individual variation in expression of $\mathrm{Ob}-\mathrm{Rb}$ by RTPCR in seven subjects. The microarray experiments did not reveal a significant change. The results obtained showed that the PEG-OB injection did not significantly change the $\mathrm{Ob}-$ $\mathrm{Rb}$ expression (fold change $=0.95, P$-value $>0.05$; data not shown).

\section{Cellular origin of inflammatory mobilized genes in WAT}

As adipose tissue contains not only adipocytes but also stromal-vascular cells, including fibroblastic connective tissue cells, preadipocytes (not yet filled with lipids) as well as leucocytes and macrophages [28], we further examined whether the inflammatory-related genes regulated by the 
Cluster 1-Immune response (84 genes)

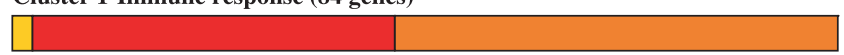

Cluster 2-Inflammatory response (34 genes)
Adipocyte (2 genes)

$\square$ SVF (34 genes)

Adipocyte+SVF (48 genes)

Adipocyte (3 genes)

SVF (19 genes)

Adipocyte+SVF (12 genes)

Figure 2 Cellular origin of inflammatory related genes in white adipose tissue. The two clusters represent the enriched functions isolated with the gene ontology annotation system. The yellow, red and orange boxes represent the number of genes overexpressed in the adipocytes, stroma vascular fraction (SVF) fraction and equally in both the adipocytes and SVF fraction, respectively.

PEG-OB injection in humans were expressed mostly in adipocytes or in the stroma vascular fraction. Mature adipocytes were separated from the SVF as described in the Materials and Methods section. Among the clusters (cluster 1 and 2, Fig. 1) related to immunity and inflammation pathways, we sorted either genes typical of adipocytes or genes mostly expressed in SVF or in both fractions. As shown in Fig. 2, most of the inflammatory related genes were mainly expressed in the SVF or equally expressed in adipocyte and SVF. The fraction of genes mainly expressed in adipose cells was faint.

\section{Discussion}

The existence of the leptin effect on WAT or isolated adipocytes is a matter of controversy. The leptin target genes in human WAT are unknown. Although both mRNA and protein of the leptin receptor (Ob-Rb) were detected on human adipocytes [29], leptin treatment in different systems led to divergent results. Several studies provide some evidences of an effect of leptin both in vitro on isolated murine adipocytes [30] and in vivo in WAT from rodents $[31,32]$. In contrast, in other studies no effect of leptin on WAT gene expression was found $[33,34]$. Our experiment showed that the supraphysiological PEG-OB injection in healthy individuals induced transcriptional changes in WAT and most of these genes were downly expressed. We also found that most of these genes belong to the inflammatory and immune functional class.

In vitro and in vivo studies have suggested a potential role for leptin in modulating the immune response [8]. The leptin receptor is structurally related to the class 1 cytokine receptor family and has been shown to have signalling capabilities of interleukin-6-type cytokine receptors [35]. The first observations were carried out on rodents with genetic leptin (ob/ob) or leptin receptor (db/db) deficiency. These mice elicit macrophage phagocytosis and the overexpression of proinflammatory cytokines [36]. Administration of exogenous leptin to ob/ob mice reversed the inflammation associated phenotype [36]. In most of the available publications, a proinflammatory function of leptin on immune cells (lympocytes, monocytes) was described $[37,38]$. No study has demonstrated such effects in human adipose tissue or adipocytes. In addition, in human monocytes, leptin was shown to induce the expression and the secretion of IL-1Ra, an interleukin widely recognized as an anti-inflammatory factor in vitro [39]. Another study showed that an increase in circulating leptin in monkey blunts the cytokine response to an inflammatory challenge [40].

One explanation of the down-regulated effect of PEG-OB in WAT might be associated with the supraphysiological dose of PEG-OB used in these healthy subjects. As expected, the PEG-OB injection induced very high plasma leptin levels in all the subjects. At this dose, many physiological pathways could be down-regulated. In this regard, we observed that most of the genes were down-regulated in our experience, including factors involved in metabolism, signal transduction, extracellular matrix and cytoskeleton.

To date, all human PEG-OB injection trials have not shown large effects. In the present study no other major physiological change on energy metabolism or hormonal status was observed. However, analyzing the pro-inflammatory status in one of our weight reduction studies using the PEGOB injection, we found an additional significant decrease of inflammatory markers as a whole [41]. It was concluded that the apparently higher decline in inflammatory parameters in the PEG-OB treated group may be related to the higher weight loss in this group. The present study provides additional information regarding the anti-inflammatory effect of PEG-OB especially in WAT.

In our study, we observed a trend toward an increase of circulating levels of the pro-inflammatory factors (CRP and SAA) after the PEG-OB injection. The mechanism by which leptin increased CRP and SAA in this study is not known but could relate to an acute-phase response. There is no confirmation that CRP and SAA could be produced by the WAT in this context. Indeed, in nonobese subjects CRP and SAA are mainly produced by the liver [42]. The CRP and SAA are classical and highly sensitive acute-phase proteins; plasma levels that typically increase by 100 -fold or more during inflammation. The twofold increase in CRP levels and threefold increase of SAA upon the PEG-OB injection are indicative of only a weak inflammatory response and may result from the direct interaction of leptin on hepatocytes via its receptor. This kind of interaction has been reported to induce IL-6-type responses [43,44]. These observations are in line with the strong correlation found between CRP and SAA changes upon a PEG-OB injection. 
In our study, we showed a decreased gene expression 3 days after PEG-OB administration in WAT, but we cannot exclude that in the first few days the inflammatory gene expression responded differently to PEG-OB administration. To investigate this possibility, future kinetic studies might be of interest.

\section{Conclusions}

In this study, we have characterized the WAT gene expression profile after 3 days in response to the administration of PEG-OB in a single supraphysiological dose. Most of these genes showed a decreased expression after the PEGOB injection. Sorting the PEG-OB regulated genes into functional classes, we observed that genes related to the inflammation and immunity classes were significantly affected by PEG-OB.

\section{Acknowledgements}

This work was supported by INSERM 'Avenir' contract and BQR of Paris 6 University. Soraya Taleb is funded by INSERM, ADR Paris 6, Saint-Antoine, Paris and 'Conseil Régional de l'Ile-de-France'. Inserm U755, U586 and LIM $\&$ BIO received a grant from the PRNH Inserm (No. A04103DS).

\section{References}

1 Halaas JL, Gajiwala KS, Maffei M, Cohen SL, Chait BT, Rabinowitz D et al. Weight-reducing effects of the plasma protein encoded by the obese gene. Science 1995;269 (5223):543-6.

2 Campfield LA, Smith FJ, Guisez Y, Devos R, Burn P. Recombinant mouse OB protein: evidence for a peripheral signal linking adiposity and central neural networks. Science 1995;269 (5223):546-9.

3 Maffei M, Halaas J, Ravussin E, Pratley RE, Lee GH, Zhang $\mathrm{Y}$ et al. Leptin levels in human and rodent: measurement of plasma leptin and ob RNA in obese and weight-reduced subjects. Nat Med 1995;1 (11):1155-61.

4 Considine RV, Sinha MK, Heiman ML, Kriauciunas A, Stephens TW, Nyce MR et al. Serum immunoreactive-leptin concentrations in normal-weight and obese humans. $N$ Engl $\mathcal{F}$ Med 1996;334 (5):292-5.

5 Schwartz MW, Woods SC, Seeley RJ, Barsh GS, Baskin DG, Leibel RL. Is the energy homeostasis system inherently biased toward weight gain? Diabetes 2003;52 (2):232-8.

6 Emilsson V, Liu YL, Cawthorne MA, Morton NM, Davenport $M$. Expression of the functional leptin receptor mRNA in pancreatic islets and direct inhibitory action of leptin on insulin secretion. Diabetes 1997;46 (2):313-6.

7 Zachow RJ, Magoffin DA. Direct intraovarian effects of leptin: impairment of the synergistic action of insulin-like growth factor-I on follicle-stimulating hormone-dependent estradiol17 beta production by rat ovarian granulosa cells. Endocrinology 1997;138 (2):847-50.
8 La Cava A, Matarese G. The weight of leptin in immunity. Nat Rev Immunol 2004;4 (5):371-9.

9 Minokoshi Y, Kim YB, Peroni OD, Fryer LG, Muller C, Carling D et al. Leptin stimulates fatty-acid oxidation by activating AMP-activated protein kinase. Nature 2002;415 (6869):339-43.

10 Siegrist-Kaiser CA, Pauli V, Juge-Aubry CE, Boss O, Pernin A, Chin WW et al. Direct effects of leptin on brown and white adipose tissue. F Clin Invest 1997;100 (11):2858-64.

11 Zierath JR, Frevert EU, Ryder JW, Berggren PO, Kahn BB. Evidence against a direct effect of leptin on glucose transport in skeletal muscle and adipocytes. Diabetes 1998;47 (1):1-4.

12 Farooqi IS, Jebb SA, Langmack G, Lawrence E, Cheetham $\mathrm{CH}$, Prentice AM et al. Effects of recombinant leptin therapy in a child with congenital leptin deficiency. $N$ Engl $\mathcal{F ~ M e d ~}$ 1999;341 (12):879-84.

13 Caro JF, Kolaczynski JW, Nyce MR, Ohannesian JP, Opentanova I, Goldman WH et al. Decreased cerebrospinalfluid/serum leptin ratio in obesity: a possible mechanism for leptin resistance. Lancet 1996;348 (9021):159-61.

14 Heymsfield SB, Greenberg AS, Fujioka K, Dixon RM, Kushner R, Hunt $\mathrm{T}$ et al. Recombinant leptin for weight loss in obese and lean adults: a randomized, controlled, doseescalation trial. fama 1999;282 (16):1568-75.

15 Hukshorn CJ, Saris WH, Westerterp-Plantenga MS, Farid AR, Smith FJ, Campfield LA. Weekly subcutaneous pegylated recombinant native human leptin (PEG-OB) administration in obese men. F Clin Endocrinol Metab 2000;85 (11):4003-9.

16 Proietto J, Thorburn AW. The therapeutic potential of leptin. Expert Opin Invest Drugs 2003;12 (3):373-8.

17 Hukshorn CJ, Saris WH. Leptin and energy expenditure. Curr Opin Clin Nutr Metab Care 2004;7 (6):629-33.

18 Hukshorn CJ, Westerterp-Plantenga MS, Saris WH. Pegylated human recombinant leptin (PEG-OB) causes additional weight loss in severely energy-restricted, overweight men. Am f Clin Nutr 2003;77 (4):771-6.

19 Eckel LA, Langhans W, Kahler A, Campfield LA, Smith FJ, Geary N. Chronic administration of OB protein decreases food intake by selectively reducing meal size in female rats. $A m \mathcal{F}$ Physiol 1998;275 (1 Part 2):R186-93.

20 Clement K, Viguerie N, Poitou C, Carette C, Pelloux V, Curat $\mathrm{CA}$ et al. Weight loss regulates inflammation-related genes in white adipose tissue of obese subjects. FASEB $\mathcal{F} 2004 ; 18$ (14):1657-69.

21 Feldman AL, Costouros NG, Wang E, Qian M, Marincola FM, Alexander HR et al. Advantages of mRNA amplification for microarray analysis. Biotechniques 2002;33 (4): 906-12, 914.

22 Quackenbush J. Microarray data normalization and transformation. Nat Genet 2002;32 (Suppl. ):496-501.

23 Ashburner M, Ball CA, Blake JA, Botstein D, Butler H, Cherry JM et al. Gene ontology: tool for the unification of biology. The Gene Ontology Consortium. Nat Genet 2000;25 (1):25-9.

24 Dahlquist KD, Salomonis N, Vranizan K, Lawlor SC, Conklin BR. GenMAPP, a new tool for viewing and analyzing microarray data on biological pathways. Nat Genet 2002;31 (1):19-20.

25 Horn F, Vriend G, Cohen FE. Collecting and harvesting biological data: the GPCRDB and NucleaRDB information systems. Nucl Acids Res 2001;29 (1):346-9.

26 Kanehisa M, Goto S, Kawashima S, Nakaya A. The KEGG databases at GenomeNet. Nucl Acids Res 2002;30 (1):42-6.

27 Doniger SW, Salomonis N, Dahlquist KD, Vranizan K, Lawlor SC, Conklin BR. MAPPFinder: using Gene Ontology and GenMAPP to create a global gene-expression profile from microarray data. Genome Biol 2003;4 (1):R7.

28 Weisberg SP, McCann D, Desai M, Rosenbaum M, Leibel RL, 
Ferrante AW Jr. Obesity is associated with macrophage accumulation in adipose tissue. $\mathcal{F}$ Clin Invest 2003;112 (12):1796-808.

29 Bornstein SR, Abu-Asab M, Glasow A, Path G, Hauner H, Tsokos $\mathrm{M}$ et al. Immunohistochemical and ultrastructural localization of leptin and leptin receptor in human white adipose tissue and differentiating human adipose cells in primary culture. Diabetes 2000;49 (4):532-8.

30 Machinal-Quelin F, Dieudonne MN, Leneveu MC, Pecquery R, Giudicelli Y. Proadipogenic effect of leptin on rat preadipocytes in vitro: activation of MAPK and STAT3 signaling pathways. Am $\mathcal{F}$ Physiol Cell Physiol 2002;282 (4):C853-63.

31 Huan JN, Li J, Han Y, Chen K, Wu N, Zhao AZ. Adipocyteselective reduction of the leptin receptors induced by antisense RNA leads to increased adiposity, dyslipidemia, and insulin resistance. F Biol Chem 2003;278 (46):45638-50.

32 Soukas A, Cohen P, Socci ND, Friedman JM. Leptin-specific patterns of gene expression in white adipose tissue. Genes Dev 2000;14 (8):963-80.

33 Aprath-Husmann I, Rohrig K, Gottschling-Zeller H, Skurk T, Scriba D, Birgel $\mathrm{M}$ et al. Effects of leptin on the differentiation and metabolism of human adipocytes. Int $\mathcal{F}$ Obes Relat Metab Disord 2001;25 (10):1465-70.

34 Elimam A, Kamel A, Marcus C. In vitro effects of leptin on human adipocyte metabolism. Horm Res 2002;58 (2):88-93.

35 Baumann H, Morella KK, White DW, Dembski M, Bailon PS, $\mathrm{Kim} \mathrm{H}$ et al. The full-length leptin receptor has signaling capabilities of interleukin 6-type cytokine receptors. Proc Natl Acad Sci USA 1996;93 (16):8374-8.

36 Loffreda S, Yang SQ, Lin HZ, Karp CL, Brengman ML, Wang DJ et al. Leptin regulates proinflammatory immune responses. FASEB f 1998;12 (1):57-65.
37 Martin-Romero C, Santos-Alvarez J, Goberna R, SanchezMargalet V. Human leptin enhances activation and proliferation of human circulating T lymphocytes. Cell Immunol 2000;199 (1):15-24.

38 Santos-Alvarez J, Goberna R, Sanchez-Margalet V. Human leptin stimulates proliferation and activation of human circulating monocytes. Cell Immunol 1999;194 (1):611.

39 Gabay C, Dreyer M, Pellegrinelli N, Chicheportiche R, Meier CA. Leptin directly induces the secretion of interleukin 1 receptor antagonist in human monocytes. $\mathcal{F}$ Clin Endocrinol Metab 2001;86 (2):783-91.

40 Xiao E, Xia-Zhang L, Vulliemoz NR, Ferin M, Wardlaw SL. Leptin modulates inflammatory cytokine and neuroendocrine responses to endotoxin in the primate. Endocrinology 2003;144 (10):4350-3.

41 Hukshorn CJ, Lindeman JH, Toet KH, Saris WH, Eilers PH, Westerterp-Plantenga MS et al. Leptin and the proinflammatory state associated with human obesity. $\mathcal{F}$ Clin Endocrinol Metab 2004;89 (4):1773-8.

42 Schultz DR, Arnold PI. Properties of four acute phase proteins: C-reactive protein, serum amyloid A protein, alpha 1-acid glycoprotein, and fibrinogen. Semin Arthritis Rheum 1990;20 (3): $129-47$.

43 Yap SH, Moshage HJ, Hazenberg BP, Roelofs HM, Bijzet J, Limburg PC et al. Tumor necrosis factor (TNF) inhibits interleukin (IL)-1 and/or IL-6 stimulated synthesis of Creactive protein (CRP) and serum amyloid A (SAA) in primary cultures of human hepatocytes. Biochim Biophys Acta 1991;1091 (3):405-8.

44 Faggioni R, Feingold KR, Grunfeld C. Leptin regulation of the immune response and the immunodeficiency of malnutrition. FASEB f 2001;15 (14):2565-71. 